\title{
KEY FACTORS INFLUENCING LEARNERS' ORAL FLUENCY IN ENGLISH SPEAKING CLASSES: A CASE AT A PUBLIC UNIVERSITY IN VIET NAM
}

\author{
Dinh Thị Bich Ngoc*, Tran Thi Dung \\ Hanoi University of Industry \\ 298 Cau Dien Street, Bac Tu Liem District, Hanoi
}

Received 12 March 2020

Revised 25 August 2020; Accepted 30 November 2020

\begin{abstract}
In the field of English language learning, speaking is regarded as one of the most important skills to be developed and enhanced continually as means of effective communication. In most English classes at universities, many students find it difficult to express themselves in spoken English. So this research aims to investigate prominent factors affecting fluency of second-year students in speaking skill. The study uses mixed research methods with two data collection instruments namely survey questionnaire and semi-structured interview. The participants joining the survey questionnaire include 98 English non-majored students who were taking the English speaking course in their second semester at a university. The semi-structured interviews were conducted with 15 teachers and 15 students. The findings reveal that the group of affective factors is the prominent one, and then followed by automation, error correction and performance factors influencing their oral fluency. Therefore, some useful recommendations focusing on interactive strategies to minimize learners' difficulties in oral fluency as well as develop their fluency in English speaking performance in this study could be taken into account for EFL teachers in English speaking classes.
\end{abstract}

Keywords: Oral fluency, prominent factors, fluency, fluency focus, fluency-based activities.

\section{Introduction}

"Why are students at universities quite hesitant in speaking even though they have been learning English since they were at secondary school?"

This question has usually obsessed two of us as education researchers during the time teaching speaking English language and this is also the reason that motivates us to implement this study about fluency in speaking.

Oral fluency has different levels: elementary, intermediate and advanced but it is truly not easy to reach each of these levels

\footnotetext{
* Corresponding author. Tel.: 0936848766 , Email: phibi1010@gmail.com
}

if learners follow the wrong way in learning English speaking. Achieving fluency in English language or any other languages is a goal of any serious learner at universities who desires to have better career opportunities. A quick survey by a group of teachers at a university for second-year English nonmajored students shows that the majority of students (99\%) agreed that speaking English fluently was absolutely necessary for their jobs in the future. However, when being asked about how much they liked speaking English in class, only a small number of students $(14,4 \%)$ preferred to speak English in class and more than half of them (67\%) thought that they had speaking difficulties such as a lot of 
pauses, a lot of hesitation, lack of confidence. Shumin (2002) reveals that knowing language grammatical and semantic rules are not enough to learn to speak a foreign language. Therefore, some of the key factors influencing students' oral fluency in English speaking performance should be taken into consideration and if these factors can solve the fluency problems in speaking, learners will improve their ability of speaking fluently. To speak fluently is not simply a matter of developing speaking skills and strategies, but it involves a number of factors including affective factors, cognitive factors, performance factors, linguistic factors (Thornbury, 2005). However, there are very few studies covering all factors influencing learners' fluency in speaking and realizing key factors as well. It is questionable whether only accuracy focus is enough in speaking classes or not and what key factors affect the restriction of oral fluency in language learners. This research is absolutely necessary to investigate fluency and accuracy balance in speaking class and key factors affecting learners' oral fluency in speaking classes.

The aim of the study is to find out prominent factors affecting learners' oral fluency in English speaking classes. In addition, some significant guidance is included to help minimize the problems and develop oral fluency in learners based on prominent factors examined in this study. More detailed, there is a research question of the study listed as follows:

What are the key factors that influence learners' oral fluency?

\section{Literature review}

\subsection{Definition of fluency}

There are a certain number of definitions of fluency in speaking. Fluency could be defined as the ability to have the intention to communicate without too much hesitation and too many pauses to cause barriers or incidents in communication (Nation, 1991). Bailey (2005, p. 5) states that fluency is "the capacity to speak fluidly, confidently, and at a rate consistent with the norms of the relevant native speech community." In other words, fluency is "the features which give speech the qualities of being natural and normal, including native-like use of pausing, rhythm, intonation, stress, rate of speaking, and use of interjections and interruptions" (Richards, Platt \& Weber, 1995, p. 108). In Hedge's view (1993), fluency is attributed to "the ability to link units of speech together with facility and without strain or inappropriate slowness or undue hesitation". These definitions mainly focus on the fluidness and confidence of producing speech without too much hesitations and pauses. From all the review above, it is ultimately said that fluency in speaking emphasizes more on meaning and natural requirement of the utterances rather than form or grammatical structures. In this research, the authors show that fluency plays a key point in learners' speaking skill compared to accuracy in the way that focuses learners on less hesitation, fewer pauses and the speed increase in speaking in order to reinforce learners' confidence in speaking.

\subsection{Fluency-based activities}

According to Bailey (2003), fluencybased activities include:

- Information -gap

- Jigsaw activities

- Roleplays

- Simulation

According to other researchers, fluencybased activities consist of:

- Consciousness-raising tasks (Boers, Eyckmans, Kappel, Stengers, \& 
Demecheleer, 2006).

- Rehearsal or repetition tasks (Bygate, 2002).

- The use of formulaic sequences (Wood, 2009).

- The use of lexical fillers or discourse markers (Guillot, 1999)

- Communicative free-production activities

\subsection{Fluency and accuracy in speaking class}

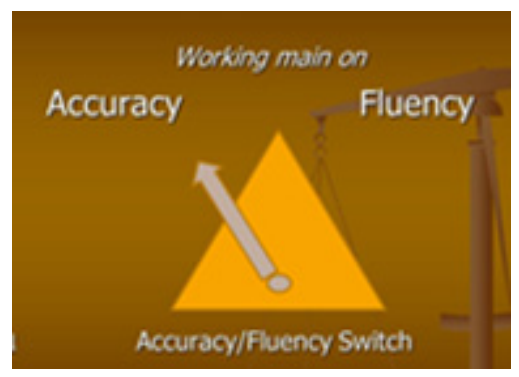

Figure 1: Accuracy/ Fluency Switch

(Adapted from Learning Teaching: A guidebook for English language teachers by Scrivener, 2005)

In speaking classes, many lesson stages emphasize both fluency and accuracy, accuracy than fluency or vice versa. The most important thing is that the teachers should be clear about the fact that they aim to focus on fluency-based work or accuracy-based work to promote learners' speaking (Scrivener, 2005). According to Figure 1 of accuracy/fluency switch, it is true that it will be the key skill if each language teacher can control fluency and accuracy-based activities in speaking class (Scrivener, 2005). In order to develop fluency in English speaking, fluency-based activities should account for one quarter of class time (Nation, 1997). Brumfit (1985) recommends a third of the total time for fluency activities from the beginning of the course and it should be increased during the course. However, there are very few classrooms in the world where fluency-based speaking activities are spent that amount of time (Mowlai \& Rahimi, 2010). Teachers traditionally tend to orient heavily to accuracy-based activities (Folse, 2010) because it is initially pressurized for teachers when examinations focus more on language knowledge than communicative competence (Gorsuch, 2000). Furthermore, focusing much on fluency can enhance more accuracy in speaking language because better speaking fluency helps improve grammar accuracy and meaning control (Nation, 1997). Making clear about what is involved in accuracy-focused work or fluency-focused work and distinguishing the different aims of the work and classroom procedures are especially important (Scrivener, 2005).

\section{Factors influencing fluency in speaking skill}

\subsection{Affective factors}

According to Dörnyei and Ryan (2015), the significant influence on the learner's language learning process is their affective side. The affective factors relate to moods, feeling, and attitudes towards language learning (Meng \& Wang, 2006) especially towards learning speaking which is researched in this study. In this study, the affective factors are considered as anxiety, shyness, selfconsciousness or confidence, fear of making mistakes, which are the key influences on fluency in speaking. These affective factors are closely related to each other as aspects of negative sides in speaking skill. Anxiety obstructs pervasively to the learning process because they worry about being "wrong, stupid, or incomprehensible" (Brown, 2001, p. 9), which will devalue their speaking performance. Additionally, too much anxiety leads to low willingness to communicate (Wu $\&$ Lin, 2014). And in the long run it will have bad effects on learners' achievement in second language classrooms. 


\subsection{Performance factors}

With regards to factors influencing fluency, performance conditions in speaking class also affect the degree of fluency in learners. According to some researchers, there are different types of performance factors which include planning time, time pressure, (Thornbury, 2005), the amount of support (Nation \& Newton, 2009). "It has been suggested that providing learners with more planning time prior to conducting the task helps learners produce more fluent and complex language" (Patanasorn, 2010). Planning time also helps learners increase not only fluency but also grammatical complexity (Yuan \& Ellis, 2003). In contrast, time pressure refers to the urgency of the speaking tasks that learners need to finish their performance which could increase the difficulty for it (Thornbury, 2005). Nguyen and Tran (2015) states that time pressure causes poor performance in speaking. Furthermore, the amount of peer and teacher support also makes things less difficult because it is easier to present a topic with others than doing it by themselves (Thornbury, 2005).

\subsection{Automation}

In Schmidt's viewpoint (1992) cited by Derwing (2017, p. 360), "oral fluency, interpreted here is as an automatic procedural skill on the part of the speaker". It is like a speed process that if it is repeated automatically by English learners, their fluency in speaking will be achieved. Levelt (1989) describes a speech process which produces speech in daily life including three stages: conceptualization, formulation and articulation. This logically mental process means that all the vague notions are made clear or conceptualized, then the speaker chooses the conveyed information based on their background information in formulation stage where grammar and lexis are arranged in the correct syntax order along with formulaic sequences and chunk language, to the last stage - articulation where the speaker uses the organs of speech to produce sounds (Thornbury, 2005). But whether speech fluency is successful, or in other words this process is formed or not depends much on learner's automation, "to some extent in conceptualization, to a considerable degree in formulation and almost entirely in articulation" (Bygate, 2001, p. 16). If the language beginners lack automation, it will be challenging for them to pay attention and produce fluent speech (Bohlke, 2014). And this is also supported by Nguyen (2015, p. 52) who points out that "fluency also derives from the automation. If students are exposed to English environment such as teachers speaking English all the time, English tapes, English books and newspapers for them to use, they can pick up language naturally and unconsciously". Good atmosphere and suitable environment can also well-support students to speak actively, correctly and fluently. If teachers regularly put students under increased time pressure, students can definitely automatize to acquire fluency in their speaking (Nguyen, 2015).

\subsection{Teacher's error corrections in speaking class}

According to Scrivener (2005), it might be less appropriate for the language teacher to use instant correction in fluency-focused tasks in a language lesson. Al-Haj and Mielke (2007) states that there is positive or negative influence on the language learning process during a correction process which occurs between teachers and learners. Correcting learners very often will demotivate them and make them afraid of speaking. In other words, "learners cannot develop fluency if the teacher is constantly interrupting them to correct their oral errors. Teachers must provide students with fluency-building practice and realize that making mistakes is a natural part of learning a new language (Bailey, 2003, p. 55). 


\subsection{Previous studies}

There are numerous studies about factors influencing learners' speaking skill in language learning in Vietnam and in the world but there are few studies about factors affecting learners' oral fluency in speaking lessons. Some are reviewed below:

In the context of China, Zhang et al. (2004) carried out a study on factors influencing Chinese college students' oral fluency in English. The results represented that the prominent factors influencing the Chinese students' oral fluency are chances of speaking English and the environment and listening and understanding of the target culture are the secondary factors. Yurong and Nan (2008) investigated how affective factors affect College English students on oral English fluency. The results of the study indicated that four affective factors determined the production of oral English. However, the limitation of the study was that these factors were studied separately. In reality, they often cooperate together to influence oral production.

In another context of Iran, Rezail and Okhovat (2016) performed a study towards how preparation and task complexity can affect L2 learners' oral fluency in speech production with respect to individual differences in working memory capacity. The findings revealed that working memory as a cognitive factor played a very important part in second language fluency and the variables Complexity and Preparation also affected second language oral performance.

And in Vietnam, Khong (2019) carried a study on the internal and external factors that affect students' fluency development at a secondary school. The results showed that there were many problems in improving students' fluency in which many factors from both students and teachers were listed such as learning styles, students' habit of using mother tongue, students' low motivation and low
English level accounting for poor vocabulary, structure, and poor pronunciation.

In fact, the previous studies only focus on single factors or groups of factors influencing learners' oral fluency. In other words, they were carried out separately or together, and in different contexts. However, these have not carried deeply in context of speaking classes and have not investigated which factors are key factors among groups of factors affecting learners' oral fluency in speaking classes. Additionally, in these studies, there was one side of the participants as learners but without the participation of teachers which played a significant role in the objective judgment about learners' fluency problems in speaking classes in order to bring reliable result. Specially, in Vietnam, there is a lack of studies on oral fluency in speaking classes. This study could solve these gaps and could help educators to know which the key factors are in order to improve learners' oral fluency.

\section{Methodology}

\subsection{Research participants}

The research participants were 98 students, including 32 males and 66 females, randomly selected from the second-year English nonmajored students of a university in Hanoi. Most of them have been learning English for about 5 to 10 years. They are taking an English course in the second semester of the academic year. This course applies blended learning method in which the students follow 35-period online and 40-period offline lessons. In each unit of the course, they self-study online five parts - vocabulary, grammar, listening, reading and writing skills. In the offline lessons at school, they just focus on speaking skill part with both accuracy-based and fluency-based activities. Before each offline lesson with their teacher in class, the students need to complete their online lesson at home. 
Besides, fifteen teachers who have been teaching English for the second-year students were also invited to take part in the interview in the study. There are two males and 13 females in this group of teachers and they have from 5 to 10 year experience in teaching English for second year university students.

\subsection{Research instruments and procedures}

This study used a mixed methods design which is the collection of both quantitative and qualitative data to understand and explain the research problem. The researchers chose survey questionnaires as the main instrument to gather quantitative data and then conducted interviews to get in-depth qualitative data for the study.

The survey questionnaire for students which consists of 8 questions was mostly adapted from the survey questionnaires conducted by Marriam, Muhammad and Ashiq (2011) and Nguyen and Tran (2015) because the questions in their surveys were suitable to collect data for our study. Besides, some questions in our survey were designed based on the theoretical knowledge related to the research topic covered in the literature review. First, the questionnaire was piloted and administered to ten second-year non-English majored students of the university who were not included in the study in order to get feedback whether the instructions and the wording questions can be understood by the research participants. After tryout and piloting, the questionnaire was reviewed by two research experts. Next, the questionnaire was delivered to the research participants. Oral instructions and explanations were given in detail to the students face-to-face by the researchers before they answered the questionnaires to avoid any misunderstandings.

Then, semi-structured one-on-one interviews for both students and teachers were carried out by the researchers. The researchers chose randomly 15 out of 98 students to conduct the individual interviews consisting of 2 questions. All 15 teachers were also included in the semi-structured one-on-one interviews composing of 4 questions. The questions of the interviews served the purpose of obtaining detailed information about the respondents' feelings in speaking classes and their opinions on some strategies used to improve oral fluency in English speaking. To get reliable data, the researchers transcribed the answers of the interviewees as immediately as possible, no more than one day after the interviews.

\subsection{Data analysis and interpretations}

The procedure of data analysis is as follows. The results of the survey questionnaire were analyzed with the help of the Google docs application and displayed in the form of statistics. Then, the data collected from the interviews were analyzed and presented parallel with the results collected from the questionnaire. In this case, the researchers compared the data taken from the questionnaire with the in-depth data from the interviews.

\section{Findings and discussion}

The major results of the study are summarized as follows:

Figure 2 illustrates the results of some problems in oral fluency activities the students were facing from the perspectives of the students.

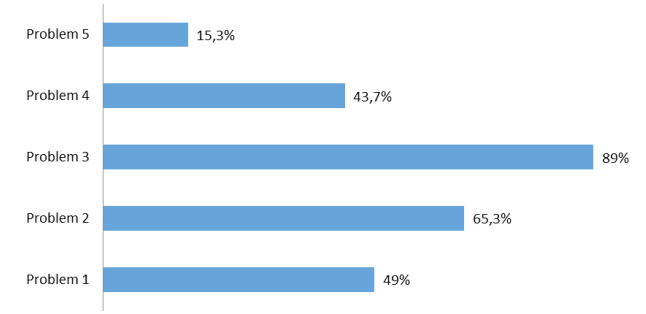

Figure 2: Students' problems in English oral fluency 
It can be seen from Figure 2 that most of the students (89\%) felt hesitant to speak English in their English classes. They hesitated to speak English because they were not sure whether they used English appropriately or not. More than a half $(65.3 \%)$ stated that they did not know whether their pauses in their English speaking chunks were suitable or not. Meanwhile, just a little under a half $(49 \%$ and $43.7 \%$ ) revealed that they could not think of anything to say or could not express the ideas in their minds in English speaking lessons, and only a small number of the students $(15.3 \%)$ chose the problem resulting from their partner's reactions.

As described in Part 4.1 above, in the English courses the students are required to complete the online lesson before each offline lesson to prepare input knowledge for their speaking activities in class. However, the results collected in Figure 2 made the researchers desire to find the causes of the students' problems. Therefore, they asked the students in their first interview question. Above two third of them (12 out of 15) shared that they prepared their online lessons before attending the offline lessons with their teachers to meet the requirements of their course. Nevertheless, they still felt nervous and afraid of making mistakes, which resulting in their hesitation and inappropriate pauses when they speak in class.

In brief, the data from Figure 2 obviously shows that hesitation is the most problematic matter among five listed problems to the students. In the study about students' speaking problems Nguyen and Tran (2015) confirms that when students want to say something in English they are sometimes inhibited. They are worried about making mistakes and fearful of criticism. Rivers (1968) thinks that learners often have nothing to say probably because their teachers select a topic that is not appropriate for them or they do not have enough information about it. Baker and Westrup (2003) also supports the results shown in Figure 1 and states that it is very difficult for learners to speak something fluently in English when they have few ideas about what to say, which vocabulary to apply, or how to use grammar accurately.

The results in Table 1 below demonstrate the factors leading to the referred problems the students faced in their oral fluency above.

Table 1: Factors affecting students' English oral fluency

\begin{tabular}{cccc}
\hline No & & Factors & Students (\%) \\
\hline 1 & Affective factor & Fear of making mistakes & 85.1 \\
& & Confidence & 82 \\
& & Anxiety & 61.8 \\
2 & Automation & Lack of speaking practice & 72.3 \\
3 & Error correction factor & Teachers' feedback on speaking activity & 70 \\
4 & Performance factor & Time for preparation & 42 \\
& & Time allowed to perform a speaking task & 10 \\
& & Listeners' support & 17.6 \\
\hline
\end{tabular}

It can be seen that the largest proportion of the students' choices fell into the group of affective factors consisting of $85.1 \%$ for "fear of making mistakes", $82 \%$ for "confidence" and $61.8 \%$ for "anxiety".
In order to make clearer about the affective factors, the question was raised in the students' interview. Answer for this second interview question, the majority of 
the students (13 out of 15) said that they felt anxious in most of their English speaking classes, which supported and confirmed the collected results in Table 1. Therefore, now the hidden reasons for the students' big problem might be revealed. In other words, the group of affective factors, especially "fear of making mistakes", was found out as the main cause of making the students hesitate to produce language in conversations. Similar to this finding, Yurong and Nan (2008) confirmed that four affective factors determined the production of oral English in their study about the effects of affective factors on students' English oral fluency. Tanveer (2007) also pointed out that students' feeling of anxiety or nervousness may impede their language learning and performance abilities. Additionally, Wu and Lin (2014) agreed with the result that too much anxiety led to low willingness to communicate. In the long run it would have bad effects on learners' achievement in a second language classroom.

Around three quarters of the students viewed automation factor - lack of speaking practice - as an influential factor to their oral fluency. This factor can be easily inferred to be the cause leading to the second problem the students suffered in Figure 2. Schmidt (1992) pointed out that if the speed process was repeated automatically by English learners daily, their fluency in speaking would achieve. Nguyen (2015, p. 52) also defended that "fluency derives from automation". Chances of speaking English and the English environment were presented as the prominent factors influencing the Chinese students' oral fluency in the study carried out by Zhang et al. (2004).Therefore, if the students do not practice speaking English regularly, they definitely cannot express themselves fluently. They might pause inappropriately in their speaking sequences or chunks of language. Besides, Bohlke (2014) ever indicated that whether the students could produce language fluently in communication or not depended much on their automation which resulted from their exposure to English environment. Students could gradually use language naturally and unconsciously thanks to diving in English speaking environment frequently. The students' exposure to English speaking environment can be seen in Table 2.

Table 2: Students' exposure to English speaking environment

\begin{tabular}{|c|c|c|c|c|c|}
\hline & $\begin{array}{c}\text { Always } \\
\%\end{array}$ & $\begin{array}{c}\text { Usually } \\
\%\end{array}$ & $\begin{array}{c}\text { Sometimes } \\
\% \\
\end{array}$ & $\begin{array}{c}\text { Rarely } \\
\%\end{array}$ & $\begin{array}{c}\text { Never } \\
\%\end{array}$ \\
\hline 1. How often do you respond in English? & 1.2 & 23.3 & 43 & 32.5 & 0 \\
\hline $\begin{array}{l}\text { 2. How often does your teacher use English } \\
\text { as a medium of instruction for teaching } \\
\text { English in your class? }\end{array}$ & 0.5 & 28.2 & 66.7 & 4.6 & 0 \\
\hline $\begin{array}{l}\text { 3. How often does your teacher translate the } \\
\text { instructions from English into Vietnamese in } \\
\text { speaking class? }\end{array}$ & 5.1 & 88.7 & 4.2 & 2 & 0 \\
\hline $\begin{array}{l}\text { 4. How often do you join these English clubs, } \\
\text { tutorial groups, etc. outside the classroom? }\end{array}$ & 8.1 & 15.3 & 35.2 & 20.4 & 11 \\
\hline
\end{tabular}


Firstly, the data in Table 2 indicates that the frequency of students' responses in English was not high with the percentage of " $43 \%, 32.5 \%, 23.3 \%, 1.2 \%$ " for the options of "sometimes, rarely, usually, always" respectively. Secondly, in terms of giving instructions, $66.7 \%$ of the participants shows that their teachers sometimes used English to give instructions in class, while $28.2 \%$ chose the option of "usually" and a very small number of them (4.6\% and $0.5 \%)$ chose the categories of "rarely" and "always" respectively. Thirdly, it can be seen from Table 2 that the large number of the students $(88.7 \%)$ agreed on the high frequency of teachers' translating instructions from English to Vietnamese in speaking class.

In the first interview question for teachers, the researchers asked them about the reasons for these dominant statistics. They explained that most of the time the students asked for the translation because they could not fully understand the instructions in English. Besides, in order to know whether the amount of time in the English classes supports the students' oral fluency or not, the teachers were interviewed about the percentage of fluency activities in each lesson in the second question. To make sure that all the teachers were clear about the features of fluency-based and accuracy based activities, the researchers explained to them briefly beforehand. All of the teachers claimed that about $50-75 \%$ of the speaking tasks in their textbook were fluency-based activities. Moreover, these tasks were always repeated in every lesson in their textbooks. Besides, they shared that all the textbooks used in their English courses were specifically designed for their own students' majors and for internal circulation only. In other words, the board of qualified English teachers of the university designed the textbooks for their own students based on their need analysis.
The data revealed that the current distribution of speaking activities in the English lessons are appropriate or even advantageous for promoting students' speaking fluency because it is much beyond the total time for fluencybased activities recommended by Brumfit (1985) as mentioned earlier in this study.

Lastly, referring to participation in some extra English activities outside the classroom, it is noticeable that the proportion of the students' frequent attendance was low with $8.1 \%$ for "always" and $15.3 \%$ for "usually". Meanwhile, the majority of them (55.6\%) sometimes and rarely joined some outsideclass English activities; even 11\% never attended any English clubs or tutorial groups. Apparently, the data in Table 2 showed that the students were currently in a limited English speaking environment outside the classroom. This fact might explain the students' difficulties in willingness to express their ideas in English without hesitation or inappropriate pauses.

Again, as can be seen from Table 1, nearly three quarters of the students thought it was the factor of error correction causing fluency problems. This factor seemed to be closely related to some affective factors presented beforehand. This meant that the students might feel shy if their speaking mistakes were mentioned by the teachers. Then, they had anxiety or fear of making mistakes in speaking class. Nguyen and Tran (2015) also reported teachers' feedback as one of the factors affecting students' speaking performance in their study. Besides, the data in Table 1 infer that the students paid much attention to the feedback or error correction on their speaking. Figure 3 showed the frequency of the teachers' error correction for their students' speaking performance. 


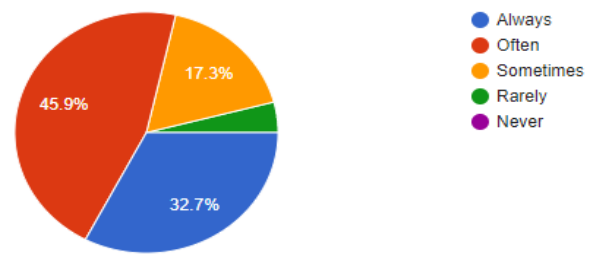

Figure 3: Frequency of the teachers' error correction

In Figure 3, over $80 \%$ of the participants stated that they were given feedback or error correction very often. Therefore, how the teachers expressed their opinions on their students' oral work was also a matter of concern and questioned in the survey. The result of this was shown in Figure 4.

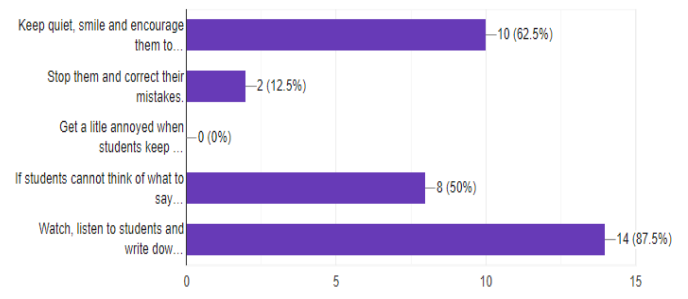

Figure 4: Teachers' reactions to students' mistakes during oral work

It can be seen from Figure 4 that most of the teachers $(87.5 \%)$ kept writing down the students' mistakes and waited until the students finished their speaking, and then gave feedback. They encouraged their students to keep speaking with their smile $(62.5 \%)$ and prompt the students forwards $(50 \%)$.

The data in Figure 4 was similar to the results the researchers obtained later from the interviews with the teachers in the third question. Most of the teachers saved their noted comments and delivered them after the students' performance. They explained that this strategy of correcting mistakes could help to maintain students' speaking without disturbing their performance or even making them lose face, etc. In addition, in return to the teachers' error correction, 14 out of 15 students answered in their last interview question that they enhanced their speaking fluency thanks to positive ways of giving feedback for their oral work from the teachers.

The last group of factors shown in Table 1 including time for preparation, time allowed to perform a speaking task and listeners' supports belonged to the category of performance factors. The small number of the students (17.6\%), under a half (42\%) and a small minority $(10 \%)$ chose the listeners' supports, the time for preparation, time allowed to perform a speaking task respectively as the factors affecting their fluency. Preparation for the task was also mentioned as a factor affecting L2 learners' oral fluency in speech production in the study performed by Rezail and Okhovat (2016).

Figure 5 revealed more detailed information about this performance factor category.

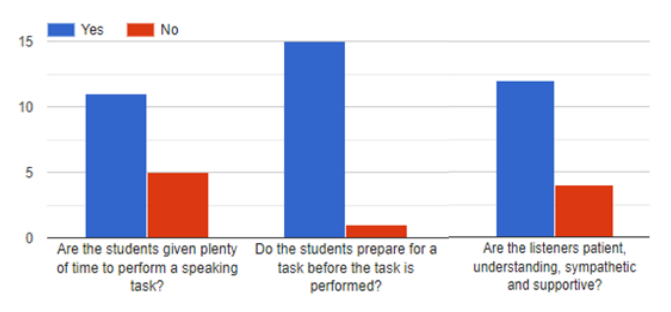

Figure 5: Performance conditions in English speaking class

Generally, students' performances were supported by both their teachers and their classmates as shown in Figure 5. They were given time to prepare as well as perform their speaking tasks. Furthermore, in the last interview question, the teachers said that they usually set a flexible time limit, ranging from 5 minutes to 12 minutes, for students' speaking performances. Besides, they also 
explained that the time limit set actually depended on the aims of each speaking task, but they always tried to help students boost their speaking fluency. The minor impacts of the performance factors on the students' speaking fluency in their current situation showed us the suitable link to the last problem the students had in table 1 .

In short, the findings from the questionnaire and interviews for the research question demonstrated that among five listed problems in English speaking classes, hesitation was recognized as the students' biggest one. Also, the group of affective factors, especially fear of making mistakes, was found out as the key factor influencing the students' oral fluency. Then, it is followed by three other factors in sequence of decreasing numbers of the students affected namely automation, error correction and performance.

To compare with some previous studies in the past, some distinctive differences in our study are shown. Specifically, research on factors affecting learners' fluency in speaking skill in language learning has been mostly limited especially about finding the key factors on speaking fluency. Zhang et al. (2004) studied factors influencing Chinese college students' oral fluency and the results were to represent the prominent factors chances of speaking English and the secondary factors - the environment of the target culture. However, in the Yurong and Nan'study (2008), the two researchers focused on how affective factors influencing College English students on oral English fluency and concluded that affective factors firmly control the process of oral output. Rezail and Okhovat's study (2016) only focus on cognitive factors in second language fluency and the variables Complexity and Preparation affecting second language oral performance. Especially in
Vietnam, Khong's study (2019) only showed some problems in improving students' fluency in which learning styles, students' habit of using mother tongue, students' low motivation and low English level accounting for poor vocabulary, structure, and poor pronunciation are listed but which key factors were not mentioned as the main problems among those in oral fluency. Additionally, the studies have some limitation of the fact that the study only focused on single factors - affective factors, cognitive factors or ranked into the prominent factors and secondary factors but there is the close relationship between factors affecting learners' oral fluency, which were the clues for researchers to compare and contrast the results. If the studies only assess single factors to come to the conclusion about the influence on learners' oral fluency, those might not be deep enough in context of speaking classes and have not indicated which factors are key factors among groups of factors influencing learners' oral fluency in speaking classes. Moreover, in these studies, there was a lack of participation in teacher interviews which played a significant role in the objective evaluation of learners' fluency problems in speaking classes in order to get reliable results. Specially, in Vietnam, there is a serious lack of studies on oral fluency in speaking classes. Our study could solve these gaps and give some suggestions for educators to indicate which the key factors in learners' oral fluency are in order to make progress to learners' oral fluency.

\section{Conclusion and Recommendations}

\subsection{Conclusion}

Achieving fluency in speaking English is an important goal for any English language learners. Accordingly, comprehending the problems related to fluency and factors causing 
these problems would contribute to assisting learners to reach this goal. In order to achieve the aim of the study, the researchers conducted the questionnaire and the interviews with the participants to answer the research question. The results for the research question displayed the students' five problems in oral fluency, namely hesitation to speak, inappropriate pauses, nothing to say, limited expressions and difficulty in replying to partners, which ranged from the biggest to the smallest one. More importantly, based on the results of data analysis, the factors leading to these problems were also revealed. The group of affective factors, especially the fear of making mistakes, was recognized as the key one to most of the participants. Then, a little fewer numbers of them were affected by automation and error correction factors. The performance factors had certain effects on a quite small number of the students in their English speaking.

\subsection{Recommendations}

Based on the results of the study, some recommendations were made for both the teachers and the students.

As for the teachers, they should first help their students overcome inhibition and shyness by providing helpful and positive feedback. The teachers should carefully decide when and how to correct the students' mistakes so that the students are not fearful of making mistakes and the flow of the students' conversation is not destroyed. Moreover, the teachers' friendly and cooperative behaviors can help make the students feel willing and comfortable to speak in the class. Secondly, it is necessary to create an English speaking environment in which both teachers and students have a habit of using English mostly inside and outside class. If the teachers give clear instructions and sufficient guidance, students can gradually get used to understanding instructions in English without translating into Vietnamese. Besides, the teachers can give students more opportunities to practice English in class by using speaking activities that require students to speak more. Especially, some fluency-based activities such as "picture description, find someone who, problem solving, information gaps, etc." which were shared by the teachers in the interviews and in the literature review as well would definitely help promote the students' oral fluency.

As for the students, they should practice speaking English as much as possible both inside and outside the classroom. Being willing to respond in English, to actively participate in speaking activities in class regularly can help to avoid the fear of making mistakes as well as to boost the confidence in speaking. Moreover, students should join speaking clubs where they can use English to communicate, which is not only helpful for their English speaking fluency but also their communication skills in general.

\section{References}

Al-Haj, M., \& Mielke, R. (2007). Cultural diversity and the empowerment of minorities: Perspectives from Israel and Germany. New York, NY: Berghahn Books.

Bailey, K. M. (2003). Speaking. In D. Nunan (Ed.), Practical English Language Teaching (pp. 47-66). Singapore: McGraw-Hill.

Bailey, K. M. (2005). Practical English Language Teaching Speaking. Boston: McGraw-Hill.

Boers, F., Eyckmans, J., Kappel, J., Stengers, H., \& Demecheleer, M. (2006). Formulaic sequences and perceived oral proficiency: Putting a lexical approach to the test. Language Teaching Research, 10, 245-261. doi:10.1191/ 13621688061r195oa

Bohlke, D. (2014). Fluency-oriented second language teaching. In M. Celce-Murcia, D. Brinton \& M. Snow (Eds.), Teaching English as a second language or foreign language (4th ed., pp. 121-135). Boston, MA: Heinle Cengage.

Brown, H. (2001). Teaching by Principles: An Interactive Approach to Language Pedagogy (2nd ed.). New York: Longman. 
Brumfit, C. (1984). Communicative Methodology in Language Teaching. Cambridge: Cambridge University Press.

Brumfit, C. (1985). Language and Literature Teaching: From Practice to Principle. Oxford: Pergamon.

Bygate, M. (2001). Effects of task repetition on the structure and control of language. In M. Bygate, P. Skehan \& M. Swain (Eds.), Researching pedagogic tasks: second language learning, teaching and testing (pp. 23-48). London: Longman.

Bygate, M. (2002). Speaking. In R. B. Kaplan (Ed.), The Oxford Handbook of Applied Linguistics (pp. 2738). Oxford: Oxford University Press.

Corder, S. P. (1967). The significance of learners' errors. International Review of Applied Linguistics in Language Teaching, 5, 161-170.

Derwing, T. (2017). L2 fluency development. In S. Loewen \& M. Sato (Eds.), The Routledge handbook of instructed second language acquisition (pp. 246259). New York, NY: Routledge.

Dörnyei, Z., \& Ryan, S. (2015). The psychology of the language learner revisited. London: Routledge.

Folse, K. S. (2010). Discussion starters: Speaking Fluency Activities for Advanced ESL/EFL Students. Michigan: University of Michigan Press.

Gorsuch, G. J. (2000). EFL educational policies and educational cultures: Influences on teachers' approval of communicative activities. TESOL Quarterly, 34(4), 675-710.

Guillot, M. N. (1999). Fluency and its teaching. Clevedon: Multilingual Matters.

Hedge T. (1993). Key concepts in ELT: fluency. ELT Journal, 47(3), 275-276.

Khong, T. T. (2019). A survey on internal and external factors influencing students' English fluency development at grade 11 in an upper secondary school in Vinh Phuc province. Masters thesis, VNU University of Languages and International Studies.

Levelt, W. J. M. (1989). Speaking: From intention to articulation. Cambridge, MA: MIT Press.

Lynch, T., \& Maclean, J. (2001). A case of exercising: Effects of immediate task repetition on learners' performance. In M. Bygate, P. Skehan \& M. Swain (Eds.), Researching pedagogic tasks: Second language learning, teaching and testing (pp. 140162). Harlow: Pearson Education.

Marriam, B., Muhammad, A., \& Ashiq, H. D. (2011). Factors Effecting Students' English Speaking Skills. British Journal of Arts and Social Sciences, 2(1), 2046-9578.

Meng, X., \& Wang, Q. (2006). Psychological factors and teachers' language. US - China Education Review, 4(5), 70-74.

Mowlai, B., \& Rahimi, A. (2010). The effect of teachers' attitude about communicative language teaching on their practice: Do they practice what they preach? ProcediaSocial and Behavioral Sciences, 9, 1524-1528.
Nation, P. (1991). Fluency Improvement in a Second Language. RELC Journal, 22(1), 84-94.

Nation, P. (1997). Developing fluency in language use. KIFL Academic Journal, 6, 30-35.

Nation, P., \& Newton, J. (2009). Teaching ESL listening and speaking. New York: Routledge.

Nguyen, H. T., \& Tran, N. M. (2015). Factors affecting students' speaking performance at Le Thanh Hien High School. Asian Journal of Educational Research, 3(2), 8-23.

Nguyen, T. T.A. (2015), The Key Principles for Development of Speaking. International Journal on Studies in English Language and Literature, 3(1), 49-53.

Patanasorn, C. (2010). Effects of Procedural Content and Task Repetition on Accuracy and Fluency in an EFL Contexts. $\mathrm{PhD}$ dissertation, Northern Arizona University.

Rezail, M., \& Okhovat, B. (2016). The effect of working memory on EFL learners' oral fluency. International Journal of English Linguistics, 6, 74-81.

Richards, J. C., Platt, J., \& Weber, H. (1986). A Dictionary of Applied Linguistics. London: Longman.

Scrivener, J. (2005). Learning teaching. Oxford: Macmillan.

Shumin, K. (2002). Factors to consider: Developing adult EFL students' speaking abilities. In J. Richards \& W. Renandya (Eds.), Methodology in language teaching: An anthology of current practice (pp. 204211). Cambridge: Cambridge University Press.

Thornbury, S. (2005). How to Teach speaking. Harlow: Longman.

Wood, D. (2009). Effects of focused instruction of formulaic sequences on fluent expression in second language narratives: A case study. Canadian Journal of Applied Linguistics, 12(1), 39-57.

Wu, C. P., \& Lin, H. J. (2014). Anxiety about speaking a foreign language as a mediator of the relation between motivation and willingness to communicate. Perceptual and Motor Skills, 119(3), 785-798.

Yashima, T. (2002). Willingness to communicate in a second language: The Japanese EFL context. The Modern Language Journal, 86, 54-66.

Yuan, F., \& Ellis, R. (2003). The effects of pretask planning and on-line planning on fluency, complexity and accuracy in L2 monologic oral production. Applied Linguistics, 24, 1-27.

Yurong, Z., \& Nan, Y. (2008). The effects of affective factors on oral English fluency of college English students. Celea Journal, 31(2), 107-116.

Zhang, D. C. et al. (2004). Analyses of factors influencing Chinese college students' oral fluency in English and the ensuing strategies in teaching. Retrieved April 14, 2020, from https://en.cnki.com. cn/Article_en/CJFDTotal-WYJY200401002.htm 


\section{APPENDIX 1 \\ SURVEY QUESTIONNAIRE FOR STUDENTS}

This survey questionnaire is designed for the study namely "Key factors influencing learners' oral fluency in English speaking class: A case study at a public university in Vietnam". Your assistance in completing the following questions is greatly appreciated. Please put a tick (v) in the box beside the option(s) you choose.

Part I: Demographic Information

1. Gender:

○ Male

- Female

2. How long have you been learning English?

Less than 5 years

○ 5 - 10 years

- Over 10 years

Part II: Factors affecting students' fluency in speaking performance

1. What problems do you encounter in English speaking? (You can choose more than one option)

- Problem 1: I cannot think of anything to say

- Problem 2: I pause suddenly and inappropriately while speaking English.

- Problem 3: I hesitate to speak English because I am not sure whether I use English appropriately or not.

- Problem 4: I don't know how to express the ideas in my mind.

- Problem 5: I can't reply because I don't understand what my partner is saying in the conversation.

2. What factors affect you the most in English speaking performance? (You can choose more than one option)

- Fear of making mistakes

○ Confidence

- Anxiety

- Teachers' feedback on speaking activity

- Time for preparation

- Time allowed to perform a speaking task

○ Listeners' support

- Lack of background information

- Lack of grammar and lexis

3. How are the performance conditions in English speaking class? (You can put as many ticks as you want)

\begin{tabular}{|c|c|c|}
\hline & Yes & No \\
\hline 1. Are you given plenty of time to perform a speaking task? & & \\
\hline 2. Do you prepare for a task before the task is performed? & & \\
\hline 3. Do you have the pressure to perform well? & & \\
\hline 4. Are the listeners supportive? & & \\
\hline
\end{tabular}


4. How often do the teachers correct your mistakes in speaking class?
○ Always
○ Usually
- Sometimes
○ Rarely
- Never

5. What is your teacher's reaction when you make mistakes during oral work? (You can choose more than one option)

- Keep quiet, smile and encourage you to go on your task.

- Stop you and correct your mistakes.

- Get a little annoyed when you keep making mistakes.

○ If you cannot think of what to say, they may prompt you forwards.

- Watch, listen to you and write down points to give feedback afterwards.

○ Others:

6. Conditions of English speaking environment

\begin{tabular}{|c|l|l|l|l|l|}
\hline $\begin{array}{r}\text { 1. How often do you speak English in } \\
\text { classrooms? }\end{array}$ & Always & Usually & Sometimes & Rarely & Never \\
\hline $\begin{array}{c}\text { 2. How often does your teacher use English } \\
\text { as a medium of instruction in your class? }\end{array}$ & & & & & \\
\hline $\begin{array}{c}\text { 3. How often does your teacher translate the } \\
\text { instructions from English into Vietnamese } \\
\text { in speaking class? }\end{array}$ & & & & & \\
\hline $\begin{array}{c}\text { 4. How often does your teacher speak } \\
\text { Vietnamese while teaching speaking } \\
\text { English in the class }\end{array}$ & & & & & \\
\hline $\begin{array}{c}\text { 5. How often do you join these English } \\
\text { clubs, tutorial groups, etc. outside the } \\
\text { classroom? }\end{array}$ & & & & & \\
\hline
\end{tabular}

Thank you very much for taking your valuable time to complete this survey. Your opinions are greatly appreciated.

\section{APPENDIX 2}

\section{QUESTIONS FOR INTERVIEW}

\section{For teachers} Why?

1. How often do you translate the instructions from English to Vietnamese in speaking classes?

2. How much percentage of fluency activities (small talk, picture description, find someone who, problem solving, information-gap activities, etc.) are there in each English speaking lesson? Please answer as detailed as possible.

3. When do you often correct your students' mistakes: during or after their English speaking? Why? 
4. How often do you set time pressure for your students' speaking performance or let them speak all the things they've prepared for their talk? Why?

\title{
For students
}

1. Do you prepare your online lessons before attending the offline lessons? Why are you still not sure whether you use English appropriately or not?

2. How do you generally feel when practicing speaking in each English speaking lesson?

3. Does your teachers' error correction help to improve your English speaking fluency? Why/ Why not?

\section{CÁC NHÂN TỐ QUAN TRỌNG ẢNH HƯỞNG ĐẾN MỨC ĐỘ NÓI TRÔI CHẢY CỦA NGƯỜI HỌC TRONG LỚP HỌC NÓI TIẾNG ANH: MỘT TRƯỜNG HỢP CỤ THỀ TẠI MỘT TRƯỜNG ĐẠI HỌC CÔNG LẬP Ở VIẸT NAM}

\author{
Đinh Thị Bích Ngọc, Trần Thị Dung \\ Đại học Công nghiệp Hà Nội \\ 298 Đường Cầu Diễn, Quận Bắc Tù Liêm, Hà Nội
}

Tóm tắt: Trong lĩnh vực học ngoại ngữ, kỹ năng nói được coi là một trong những kỹ năng quan trọng nhất cần được phát triển và nâng cao liên tục để đảm bảo giao tiếp hiệu quả. Trong hầu hết các lớp học tiếng Anh ở bậc đại học, sinh viên thường gặp khó khăn trong việc diễn đạt ý tưởng bằng tiếng Anh. Vì vậy, nghiên cứu này được thực hiện nhằm tìm ra yếu tố quan trọng ảnh hưởng đến việc nói tiếng Anh trôi chảy của sinh viên năm thứ hai. Nghiên cứu này sử dụng phương pháp nghiên cứu hỗn hợp, trong đó bảng điều tra và phỏng vấn được áp dụng làm công cụ để thu thập dữ liệu định lượng và định tính cho nghiên cứu. Có 98 sinh viên năm thứ hai thuộc hệ không chuyên tiếng Anh tham gia trả lời câu hỏi trong bảng điều tra. Thêm vào đó, các tác giả thực hiện các cuộc phỏng vấn cá nhân với 15 giáo viên và 15 sinh viên trong nhóm trên. Kết quả nghiên cứu cho thấy các nhân tố về cảm xúc chính là yếu tố nổi bật nhất ảnh hưởng đến việc nói tiếng Anh trôi chảy của sinh viên; sau đó là nhân tố về sự chủ động, việc sửa lỗi của người dạy và việc trình bày bài nói. Từ đó, các tác giả đưa ra một số đề xuất nhằm giảm thiểu những khó khăn trong việc nói tiếng Anh trôi chảy và cải thiện mức độ nói tiếng Anh trôi chảy của sinh viên. Đồng thời, đây cũng là những đề xuất hữu ích cho các giáo viên ngoại ngữ trong việc dạy kỹ năng nói cho người học.

Tù khóa: nói trôi chảy, yếu tố nổi bật, sự trôi chảy, sự tập trung vào mức độ trôi chảy, các hoạt động tập trung vào mức độ trôi chảy. 